\title{
Prospects and challenges of US and CEUS
}

\author{
Olivier Lucidarme ${ }^{1 *}$, Jean Michel Correas ${ }^{2}$ \\ From International Cancer Imaging Society (ICIS) 14th Annual Teaching Course \\ Heidelberg, Germany. 9-11 October 2014
}

Ultrasound is already a major technique to study focal liver lesions. Particularly since the arrival of the ultrasound contrast agents which allows a sensitivity greater than $90 \%$ for characterizing incidentally detected focal liver lesions in adults in whom an unenhanced ultrasound scan is inconclusive or with inconclusive MRI/ CT. However the role of ultrasound will probably rise even more in the near future because of rapid software and hardware developments.

Future prospects are:

1) The development of image fusion and navigation technology combining US and CT or MRI to improve the possibility to perform difficult percutaneous ultrasound guided biopsy or thermo ablation procedures with a higher rate of success.

2) The development of 3D imaging technology in ultrasound to improve liver tumour response assessment particularly by means of a combination with ultrasound contrast agents. The challenge will be to be able to reach a real time $3 \mathrm{D}$ imaging through matrix technologies also capable of handling contrast agents enhanced modes in order to get enhancement curves of the whole tumour with a adapted temporal resolution.

3) The development of targeted imaging through targeted microbubbles against a variety of targets located on the vessel wall. Indeed contrast enhanced ultrasound is probably the second more sensitive technique to the presence of a small amount of targeted contrast compound after PET. Many feasibility studies on animal models have already been conducted and currently a hypo allergenic targeted microbubble that includes in its membrane a heterodimer peptide having a high affinity to VEGFR2 (BR55) is being tested in humans.

Beside CT and MRI, US must be also considered as a major technique that has much to offer particularly in

\footnotetext{
* Correspondence: olivier.lucidarme@psl.ap-hop-paris.fr

'Service d'imagerie polyvalente, Groupe hospitalier Pitié-Salpêtrière, AP-HP, France

Full list of author information is available at the end of the article
}

liver imaging and the near future of ultrasound is undoubtedly exciting.

Authors' details
'Service d'imagerie polyvalente, Groupe hospitalier Pitié-Salpêtrière, AP-HP,
France. 'Service de radiologie adulte, Hôpital Necker, AP-HP, France.

Published: 9 October 2014

doi:10.1186/1470-7330-14-S1-013

Cite this article as: Lucidarme and Correas: Prospects and challenges of US and CEUS. Cancer Imaging 2014 14(Suppl 1):O13.

\section{Submit your next manuscript to BioMed Central and take full advantage of: \\ - Convenient online submission \\ - Thorough peer review \\ - No space constraints or color figure charges \\ - Immediate publication on acceptance \\ - Inclusion in PubMed, CAS, Scopus and Google Scholar \\ - Research which is freely available for redistribution \\ Submit your manuscript at www.biomedcentral.com/submit}

() Biomed Central

(c) 2014 Lucidarme and Correas; licensee BioMed Central Ltd. This is an Open Access article distributed under the terms of the Creative Commons Attribution License (http://creativecommons.org/licenses/by/4.0), which permits unrestricted use, distribution, and reproduction in any medium, provided the original work is properly cited. The Creative Commons Public Domain Dedication waiver (http://creativecommons.org/publicdomain/zero/1.0/) applies to the data made available in this article, unless otherwise stated. 